\title{
An Empirical Study on Factors Affecting Continuance Intention of Using Yu'e Bao
}

\author{
Qihua LIU, Fuguo ZHANG, Mingsong MAO, Bingyu XUE, Zhifang LIN
}

\begin{abstract}
The success of Internet investment products such as Yu'e Bao directly relies on users' continuous participation. However, few researches have examined Internet investment products from the context of post-adoption. The purpose of this paper is to study continuance usage intention toward Yu'e Bao, a prevalent Internet investment product. The dual-process model (DPM) has been used in several studies of information systems continuance. We have extended the DPM by examining the impact of some critical factors that directly influence continuance usage intention including expected earnings, capital liquidity and perceived risk. We used structural equation modelling to validate the proposed model and hypotheses. We discover that perceived usefulness, perceived enjoyment, satisfaction, loyalty, habit, expected earnings and capital liquidity positively influence continuance intention. Perceived risk has a negative effect on continuance usage intention. Furthermore, the results also demonstrate that expected earnings and capital liquidity have positive impacts on users' perceived risk. The capital liquidity has negative influence on expected earnings. The results provide important implications for research and practice in the field of information systems and finance.
\end{abstract}

Keywords: capital liquidity; continuance usage intention; dual-process model; expected earnings; Internet investment products; perceived risk

\section{INTRODUCTION}

Internet investment products have become very popular in China. Based on the new data from CNNIC, in 2016, China had 101 million Internet users who purchased Internet investment products, increased by 11.13 million more than at the end of 2015 , and the utilization rate was $14.3 \%$, an increase of 1.3 percentage points [1].

Yu'e Bao is one of the Internet investment products that was offered on June 13, 2013 by Alibaba affiliated Ant Financial Services Group. The product's Chinese name, which means "leftover treasure", hints at its origins as an account created to hold cash left idle in the accounts Ant Financial customers created to pay for purchases. Most users transfer small payments (such as acquaintance payments and online shopping refunds) to Yu'e Bao. Yu'e Bao is currently the largest money market in the world. As of March 2017, Yu'e Bao has a global user amounts and assets of 300 million and $\$ 163.3$ billion, respectively. However, in the process of rapid development, Yu'e Bao also encountered some great challenges. On the one hand, after the emergence of Yu'e Bao, the other Internet investment products such as WeChat Licaitong and Baidu Baifa have also appeared. Moreover, some commercial banks have also financial innovation for investors to provide more choices. So, the competition of Internet investment products is becoming increasingly fierce. On the other hand, at present, most of the Internet investment products are experiencing a decline in earnings and capital stock size growth rate. Currently, the scale of Internet investment users has entered a steady stage. The question to be asked are what needs is fulfilled by Yu'e Bao and what motivational factors make individuals continue to use Yu'e Bao.

In this paper, we examine two roles Yu'e Bao plays: Yu'e Bao as an IS, and Yu'e Bao as an investment product. From a technological perspective, Yu'e Bao is a kind of financial information system (IS). A service provider operating the online technological platform, Yu'e Bao users volunteer to join and use the platform. Hence, the relevant IS continuation theories are helpful to understand the user behaviour of Yu'e Bao. In general, the extant IS continuance models can be mainly classified as analytic based (AB) models, the emotion based (EB) models, and the habit/automaticity perspective (HAP). They reveal three processes that interact but differently. However, human cognition is often determined by multiple processes and their interactions, rather than by a single process. Compared to a single model, a comprehensive model consisting of an AB model, an EB model, and HAP often has the advantage of elucidating the possible disassociation between the identified predictors and IS intentions. The dual-process model (DPM) seeks an answer to this question [2]. Based on the theories of dual-process decision making, Gwebu et al. (2014) theoretically integrated above three post-adoption continuation models as well as examined DPM's potential value, which assimilated the pivotal elements of the competing continuance models [2]. Through Facebook users' responses, Gwebu et al. (2014) found that the integrated model has better performance and persuasiveness in analysing the continuous intent of SNS users. In the literature, the DPM also has been used in several studies of IS continuance such as online carbon footprint calculator [3], social network services [4] and Mobile Banking [5]. However, few studies have applied DPM to study user behaviour of Internet investment products.

Yu'e Bao, in addition to being IS, is primarily an investment product. Yu'e Bao users can invest some funds such as their idle Alipay account balances in a money market fund. Therefore, the theory of investment behaviour is very important for studying the continuance intention of using Yu'e Bao. According to the theory of investment behaviour, the avoidance of investor risk can reduce the risk of investment process, but which also gives up the opportunity to obtain greater returns. So, investors tend to pursue a balance between risk and profitability [6]. In addition, the reason for investors' demand for liquidity is that they face privately observed risks [7]. Therefore, from the perspective of investment products, risk, earning and liquidity are three important factors that affect the user's investment decision-making.

The purpose of this paper is to contribute a theoretical extension of the DPM's use to empirically investigate the effects of expected earnings, capital liquidity and perceived risk on users' continuance intention toward Yu'e 
Bao. The findings have significant implications for developers and managers of Internet investment products, since the success of an Internet investment product such as Yu'e Bao directly relies on users' continuous participation and usage.

\section{THEORETICAL BACKGROUND AND HYPOTHESES}

This research investigates the effects of crucial constructs on continuance usage intention of Yu'e Bao. We proposed a research model that includes not only all of the constructs and relationships of the DPM but also the following additional constructs: expected earnings, capital liquidity and perceived risk. The theoretical framework is shown in Fig. 1.

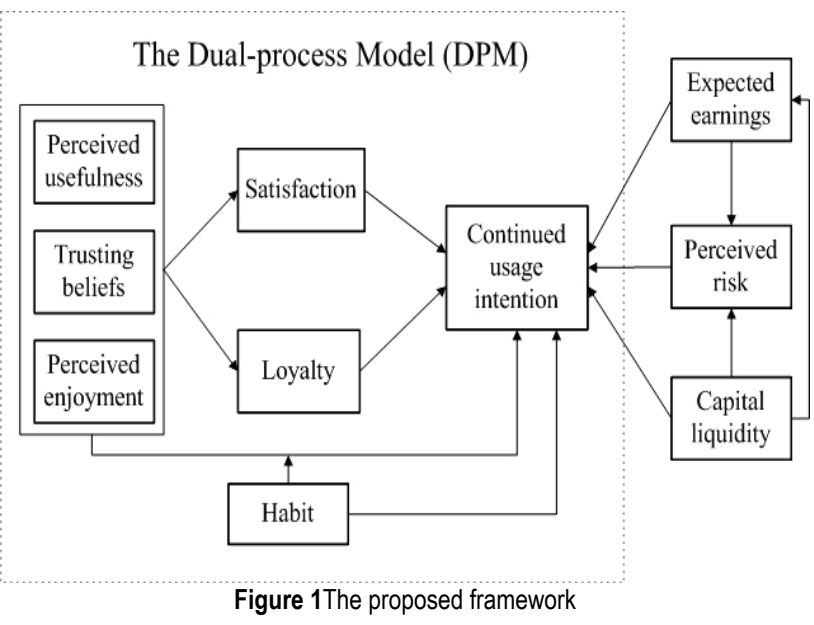

\subsection{The Dual-Process Model}

The existing IS continuous model represents the various parts of the cognitive continuum. The dual process theory of decision-making serves the purpose of concept integration, placing the existing IS continuous models under a common umbrella [8-10]. The DPM of IS continuance is based on integrating the $\mathrm{AB}$ models, $\mathrm{EB}$ models, and HAP.

AB models exploit the theory of reasoned action (TRA) and technology acceptance model (TAM) to explain continuance intentions of IS users. Perceived usefulness, perceived enjoyment and trusting beliefs are the three post adoption beliefs in AB models [11].

EB models recognize that the emotion is very important in decision making. Moreover, many existing IS continuance models have used satisfaction and loyalty as important predictors of users' continuance intentions. Satisfaction refers to evaluation and emotional response of users to the overall experience of a particular system [12]. Among EB models, the expectation-confirmation model (ECM) is one of the most-used one, which stresses the impact of satisfaction in user decision making. The ECM, proposed by Oliver (1980), is utilized to understand how satisfied consumers are with a product or service, and how this level of satisfaction affects their willingness to repurchase the products [13]. Bhattacherjee (2001) integrated TAM with the ECM to understand users' continued use intentions on an IS [14]. ECM shows that both satisfaction and perceived usefulness of IS users will be affected from affirmation of previous expectations.
Moreover, the satisfaction and perceived usefulness may have the important effects on continued usage intentions of IS users. Loyalty has been defined as a combination of attitude and behavioural characteristics [15]. The behavioural aspect is defined as intention to make repeated purchases, while the attitudinal one refers to continuous preference or favourable attitude toward certain services or a certain product or firm. In spite of situational influences, marketing efforts, and short-term changes in the performance of the product or service, loyalty is relatively stable, that is why loyalty should be an important construct in the study of IT continuance [15-19]. That affective loyalty serves as a significant and consistent predictor of individuals' repurchasing and continuance decisions has been strongly supported by empirical studies [20]. Moreover, previous research has found that satisfaction plays a key role in achieving customers' loyalty [15, 21].

HAP suggests that habit plays a significant role when users continue to use a certain IS. When a person regularly repeats an action and enjoys doing so, the action naturally becomes habitual [22]. In the context of IS, habit is defined as the extent of use of a particular information system becoming automatic in certain situations [23]. Many previous studies have found that habit has an important impact on the continued use of information system users [24-27]. Habit can directly affect the continued intents of the IS because once you get used to certain behaviours, individuals will tend to ignore any alternatives, and even isolate them from the incentives and benefits of alternatives. The action of using an IS and the increasing confidence of using it may promote mutually, as a result, in a sort of habituated manner, the behaviour of repeatedly using one same IS may be inspirable. Once developed, the habit of using a particular IS will be capable of resisting alternatives and enhancing continuance intentions.

This study adds to the body of knowledge on Internet investment products by examining whether the relationships proposed in the DPM apply to the use of Yu'e Bao in China. Hence, we propose the following:

H1. Perceived usefulness has a positive effect on continuance intention toward Yu'e Bao.

H2. Trusting beliefs have a positive effect on continuance intention toward Yu'e Bao.

H3. Perceived enjoyment has a positive effect on continuance intention toward Yu'e Bao.

H4. Satisfaction has a positive effect on continuance intention toward Yu'e Bao.

H5. Loyalty has a positive effect on continuance intention toward Yu'e Bao.

H6. Satisfaction has a positive effect on loyalty toward Yu'e Bao.

H7. Perceived usefulness has a positive effect on satisfaction toward Yu'e Bao.

H8. Trusting beliefs have a positive effect on satisfaction toward Yu'e Bao.

H9. Perceived enjoyment has a positive effect on satisfaction toward Yu'e Bao.

H10. Perceived usefulness has a positive effect on loyalty toward Yu'e Bao.

H11. Trusting beliefs have a positive effect on loyalty toward Yu'e Bao.

H12. Perceived enjoyment has a positive effect on loyalty toward Yu'e Bao. 
H13. Habit has a positive effect on continuance intention toward Yu'e Bao.

H14. Habit positively mediates the relationship between perceived usefulness and continuance intention.

H15. Habit positively mediates the relationship between trusting beliefs and continuance intention.

H16. Habit positively mediates the relationship between perceived enjoyment and continuance intention.

\subsection{Additional Constructs}

This study extends the DPM with three particular constructs: expected earnings, capital liquidity and perceived risk. The purpose of most customers to use Internet investment products is to obtain earnings. Previous research has confirmed that expected earnings have a significant impact on the initial adoption behaviour and continued use intentions toward a financial product [28-30] Thus we propose that:

H17. Expected earnings have a positive effect on continuance intention toward Yu'e Bao.

Capital liquidity is defined here as the amount of funds that can be quickly used for investment and expenditure. High liquidity means that investment funds are easy or quick to be traded and redeemed. Low or tight liquidity means that funds used for investment are difficult or expensive to be traded and redeemed. Capital liquidity towards an Internet investment product could be an important mechanism through which users develop their continuance intentions [31]. If an Internet investment product has high liquidity, users are more likely to invest their idle money in this product and intend to continue to use it. Moreover, high mobility also means that the Internet investment platform needs to pay more, which will have a negative impact on the expected earnings of the investment product. Thus we propose that:

H18. Capital liquidity has a positive effect on continuance intention toward Yu'e Bao.

H19. Capital liquidity has a negative effect on expected earnings.

Perceived risk is defined as the loss that can occur when pursuing the desired outcome of using an Internet investment product [32]. According to Ostlund (1974), consumers' actions can have negative consequences, which result in a momentous well-established notion in consumer behaviour: perceived risk [33]. As a form of Internet finance, the Internet investment products do not change the core functions of traditional finance and the connotation of financial contract, which face both the traditional financial risks and the risks of reflecting the characteristics of the Internet [34]. According to the theory of investment behaviour, the greater the benefits of financial products, the greater the risk will be. In addition, if an Internet investment product has high liquidity customers are more likely to quickly recover costs and benefits, thereby reducing their perceived risk. Previous research has found that perceived risk is an important factor that impacts on consumer decisions and behaviours [35]. Thus, we propose that:

H20. Expected earnings will positively influence Perceived risk.
H21. Capital liquidity will negatively influence Perceived risk.

H22. Perceived risk has a negative influence on continuance intention toward Yu'e Bao.

\section{RESEARCH METHODOLOGY \\ 3.1 Data Collection and Sample}

Our research adopted a Web-based survey of Yu'e Bao users to examine the research model and hypotheses. The questionnaire was first designed in English and then translated into Chinese. In consideration of the reliability of the Chinese translation, we assigned two authors to translate all original items into Chinese separately. Next, the third Chinese-speaking researcher affirmed the meaning of the English version through comparing the two Chinese translations. If there was any difference, the researchers would talk over the translation methods until an agreement was reached finally. After developing the initial survey, the questionnaire was tested with a pilot study involving 20 students with experience of using Yu'e Bao. The results of pilot test are used to improve ambiguous or poorly worded items. Moreover, the wording of awareness and connectedness items will also be improved. The modified questionnaire was released through Sojump.com, a professional survey service website, and lasted four months from December 2016 to March 2017. The questionnaire was spread through e-mail, QQ, WeChat and other communication tools to allow more users to participate in our survey. In total, 417 responses were received. We scrutinized and eliminated those questionnaires, which either had too many missing values or the same answers to all questions. Finally, 339 valid responses were obtained.

Table 1 Descriptive statistics of respondents' characteristics

\begin{tabular}{|c|c|c|c|}
\hline Measure & Category & Frequency & $\begin{array}{c}\text { Percentage } \\
(\%)\end{array}$ \\
\hline \multirow{2}{*}{ Gender } & Male & 162 & 47.8 \\
\hline & Female & 177 & 52.2 \\
\hline \multirow{6}{*}{ Age } & 16 and under & 3 & 0.9 \\
\hline & $17-28$ & 224 & 66.1 \\
\hline & $29-35$ & 87 & 25.7 \\
\hline & $36-44$ & 19 & 5.6 \\
\hline & $45-60$ & 2 & 0.6 \\
\hline & Over 60 & 4 & 1.2 \\
\hline \multirow{4}{*}{ Education level } & Doctorate & 2 & 0.6 \\
\hline & Master's degree & 124 & 36.6 \\
\hline & Bachelor's degree & 171 & 50.4 \\
\hline & Others & 42 & 12.4 \\
\hline \multirow{4}{*}{ Time of use } & Half year & 37 & 10.9 \\
\hline & Half year-one year & 38 & 11.2 \\
\hline & One year-three years & 157 & 46.3 \\
\hline & Over three years & 107 & 31.6 \\
\hline \multirow{5}{*}{$\begin{array}{l}\text { Monthly disposable } \\
\text { income (RMB) }\end{array}$} & Below 800 & 40 & 11.7 \\
\hline & $800-1500$ & 87 & 25.8 \\
\hline & $1500-3000$ & 78 & 23.0 \\
\hline & $3000-6000$ & 82 & 24.2 \\
\hline & Over 6000 & 52 & 15.3 \\
\hline \multirow{4}{*}{$\begin{array}{c}\text { Individual Yu'e Bao } \\
\text { accounts balances }\end{array}$} & Below 1000 & 210 & 61.9 \\
\hline & $1000-10000$ & 94 & 27.7 \\
\hline & $10000-100,000$ & 31 & 9.1 \\
\hline & Over 100,000 & 4 & 1.2 \\
\hline
\end{tabular}

As shown in Tab. 1, 47.8\% respondents were male and $52.2 \%$ were female, with $66.1 \%$ respondents between 17 and 28 years old. The majority of respondents were under 
35 years old $(91.8 \%) .50 .4 \%$ respondents held a bachelor's degree. $77.9 \%$ respondents use WeChat for not less than one year. Monthly disposable income of $48.8 \%$ respondents ranges from 800 to $3000 \mathrm{RMB}$. Individual Yu'e Bao accounts of $61.9 \%$ respondents have balances of less than 1,000 RMB. The results of this survey were nearly consistent with the reported by Xinhua [33]. According to Xinhua [33], more than 70\% of Yu'e Bao users' account balance is less than 1,000 Yuan [36]. Above-mentioned descriptions provided supports for the point that our sample was unaffected by non-response bias.

\subsection{Instrument Development}

The questionnaire for this study consists of two parts. The first part contains six questions, which are associated with demographic information in Tab. 1. The second part includes 39 items for measuring the constructs of perceived usefulness ( 5 items), trusting beliefs (4 items), perceived enjoyment (3 items), satisfaction ( 4 items), loyalty (4 items), habit (4 items), expected earnings (4 items), capital liquidity (4 items), perceived risk (4 items), and continuance intention ( 3 items). We adopted the 5-point Likert scales that range from "strongly disagree" to "strongly agree" to measure each construct item in part two.

All construct items used in our research were selected from previously validated measurements and had been slightly modified to fit the specific context under Internet investment products. The scales for perceived usefulness (PU) were derived from Lin and $\mathrm{Lu}$ [37] while the questions for perceived enjoyment (PE) came from work of Lin and Bhattacherjee [38]. The questions used in the trusting beliefs (TB) were derived from Gwebu et al. [2]. The measure for loyalty (LO) and satisfaction (SA) was developed from Kim and Son [39] and Kang et al. [40] respectively. The questions used in the habit (HA) came from Chiu et al. [24]. The questions for expected earnings (EE) were derived from Chen [26] while the scales for capital liquidity (CL) came from work of Eljelly [6]. The measure for perceived risk (PR) was developed from Lee et al. [41]. The questions for continuance intention (CI) were derived from Mouakket [42].

\section{RESULTS \\ 4.1 Testing the Validity and Reliability of Constructs}

We exploited the software IBM SPSS Amos 22.0 and SPSS 19.0 to examine the reliability and validity of the measurement model. The results have shown that all the Cronbach's alpha $(\alpha)$ values exceeded the 0.70 level, which evinced that any one of the measures had all acceptable reliability in terms of their respective constructs (see Tab. 2).

To evaluate the latent variables' convergent validity, confirmatory factor analysis was used. Convergent validity meant the degree to which the same construct is measured by two or more items. Factor loadings, average variance extracted (AVE), and composite reliability (CR) were exploited to test the convergent validity of the items. As shown in Tab. 3, the factor loading of every remaining item is higher than 0.50 , manifesting that all items are more than the recommended factor loading value [43]. The AVE values of all items exceed the 0.50 threshold [44]. The composite reliability was used to measure the internal consistency. The results show that all the composite reliabilities meet the minimum required level of 0.70 [44]. Thus, all the measures are reliable and valid.

Table 2 Construct and Cronbach's alpha value

\begin{tabular}{|c|c|c|c|}
\hline Construct & Number of items & Cronbach's alpha $(\alpha)$ & Reference Value \\
\hline PU & 5 & 0.946 & \multirow{10}{*}{$\begin{array}{c}\text { Cronbach } \\
\alpha \geq 0.70\end{array}$} \\
\hline $\mathrm{PE}$ & 3 & 0.926 & \\
\hline TB & 4 & 0.911 & \\
\hline $\mathrm{LO}$ & 4 & 0.942 & \\
\hline SA & 4 & 0.951 & \\
\hline $\mathrm{HA}$ & 4 & 0.944 & \\
\hline $\mathrm{EE}$ & 4 & 0.845 & \\
\hline $\mathrm{CL}$ & 4 & 0.935 & \\
\hline PR & 4 & 0.909 & \\
\hline CI & 3 & 0.774 & \\
\hline
\end{tabular}

Table 3 Results of confirmatory factor analysis

\begin{tabular}{|c|c|c|c|c|}
\hline Construct & Item & $\begin{array}{c}\text { Factor } \\
\text { loadings }\end{array}$ & $\begin{array}{c}\text { Average variance } \\
\text { extracted }\end{array}$ & $\begin{array}{c}\text { Composite } \\
\text { reliability }\end{array}$ \\
\hline \multirow{5}{*}{$\mathrm{PU}$} & PU1 & 0.733 & \multirow{5}{*}{0.610} & \multirow{5}{*}{0.886} \\
\hline & PU2 & 0.863 & & \\
\hline & PU3 & 0.832 & & \\
\hline & PU4 & 0.743 & & \\
\hline & PU5 & 0.723 & & \\
\hline \multirow{3}{*}{ PE } & PE1 & 0.875 & \multirow{3}{*}{0.807} & \multirow{3}{*}{0.926} \\
\hline & PE2 & 0.929 & & \\
\hline & PE3 & 0.890 & & \\
\hline \multirow{4}{*}{ TB } & TB1 & 0.687 & \multirow{4}{*}{0.520} & \multirow{4}{*}{0.812} \\
\hline & TB2 & 0.790 & & \\
\hline & TB3 & 0.756 & & \\
\hline & TB4 & 0.653 & & \\
\hline \multirow{4}{*}{ LO } & LO1 & 0.733 & \multirow{4}{*}{0.512} & \multirow{4}{*}{0.807} \\
\hline & $\mathrm{LO} 2$ & 0.729 & & \\
\hline & $\mathrm{LO} 3$ & 0.687 & & \\
\hline & LO4 & 0.711 & & \\
\hline \multirow{4}{*}{ SA } & SA1 & 0.685 & \multirow{4}{*}{0.550} & \multirow{4}{*}{0.830} \\
\hline & SA2 & 0.727 & & \\
\hline & SA3 & 0.784 & & \\
\hline & SA4 & 0.767 & & \\
\hline \multirow{4}{*}{ HA } & HA1 & 0.740 & \multirow{4}{*}{0.591} & \multirow{4}{*}{0.853} \\
\hline & HA2 & 0.768 & & \\
\hline & HA3 & 0.810 & & \\
\hline & HA4 & 0.756 & & \\
\hline \multirow{4}{*}{$\mathrm{EE}$} & EE1 & 0.516 & \multirow{4}{*}{0.539} & \multirow{4}{*}{0.775} \\
\hline & EE2 & 0.583 & & \\
\hline & EE3 & 0.761 & & \\
\hline & EE4 & 0.836 & & \\
\hline \multirow{4}{*}{$\mathrm{CL}$} & CL1 & 0.784 & \multirow{4}{*}{0.621} & \multirow{4}{*}{0.867} \\
\hline & CL2 & 0.864 & & \\
\hline & CL3 & 0.817 & & \\
\hline & CL4 & 0.674 & & \\
\hline \multirow{4}{*}{ PR } & PR1 & 0.762 & \multirow{4}{*}{0.522} & \multirow{4}{*}{0.811} \\
\hline & PR2 & 0.840 & & \\
\hline & PR3 & 0.690 & & \\
\hline & PR4 & 0.572 & & \\
\hline & CI1 & 0.735 & & \\
\hline CI & CI2 & 0.667 & 0.503 & 0.752 \\
\hline & CI3 & 0.724 & & \\
\hline
\end{tabular}

\subsection{Testing the Hypotheses}

We exploited the method of structural equation modelling (SEM) to examine the research model and explore the relationships between the hypotheses. Tab. 4 shown that all the fit indices $\left(X^{2} / d f\right.$, GFI, AGFI, RMSEA, CFI, TLI and IFI) were within the recommended values. Hence, the fit of our model was satisfactory. The standardized path coefficients and path significances were displayed in Tab. 5. 


\begin{tabular}{|c|c|c|c|}
\hline \multirow{2}{*}{ Fit index } & \multicolumn{2}{|c|}{ Recommended value } & \multirow{2}{*}{ Observed value } \\
\hline & Accept & Good & \\
\hline$X^{2} / d f$ & \multicolumn{2}{|c|}{$<3.0$} & 2.876 \\
\hline GFI & {$[0.7,0.9]$} & $>0.9$ & 0.761 \\
\hline AGFI & {$[0.7,0.9]$} & $>0.9$ & 0.806 \\
\hline RMSEA & $<0.08$ & $<0.05$ & 0.078 \\
\hline CFI & {$[0.7,0.9]$} & $>0.9$ & 0.907 \\
\hline TLI & {$[0.7,0.9]$} & $>0.9$ & 0.898 \\
\hline IFI & {$[0.7,0.9]$} & $>0.9$ & 0.907 \\
\hline
\end{tabular}

Table $\mathbf{5}$ The structural model: path coefficients and their levels of significance

\begin{tabular}{|c|c|c|c|c|}
\hline \multicolumn{2}{|c|}{ Hypothesis } & \multirow{2}{*}{$\begin{array}{c}\text { Path } \\
\text { Coefficients and } \\
\text { Their Levels of } \\
\text { Significance } \\
0.106^{* *}\end{array}$} & \multirow{2}{*}{$\begin{array}{c}\text { Hypothesis } \\
\text { confirmed? } \\
\mathrm{Y}(\mathrm{Yes})\end{array}$} & \multirow{2}{*}{$\begin{array}{c}\begin{array}{c}\text { Gwebu et } \\
\text { al. [2] }\end{array} \\
0.178^{* * *}\end{array}$} \\
\hline H1 & $\mathrm{PU} \rightarrow \mathrm{CI}$ & & & \\
\hline $\mathrm{H} 2$ & $\mathrm{~TB} \rightarrow \mathrm{CI}$ & 0.044 & $\mathrm{~N}(\mathrm{No})$ & 0.003 \\
\hline $\mathrm{H} 3$ & $\mathrm{PE} \rightarrow \mathrm{CI}$ & $0.082 * *$ & $\mathrm{Y}$ & $0.271 * * *$ \\
\hline $\mathrm{H} 4$ & $\mathrm{SA} \rightarrow \mathrm{CI}$ & $0.331 * * *$ & $\overline{\mathrm{Y}}$ & 0.145* \\
\hline $\mathrm{H} 5$ & $\mathrm{LO} \rightarrow \mathrm{CI}$ & $0.123 *$ & $\mathrm{Y}$ & $0.147^{*}$ \\
\hline H6 & $\mathrm{SA} \rightarrow \mathrm{LO}$ & $0.816^{* * *}$ & $\mathrm{Y}$ & $0.223 * * *$ \\
\hline $\mathrm{H} 7$ & $\mathrm{PU} \rightarrow \mathrm{SA}$ & $0.323 * * *$ & $\mathrm{Y}$ & $0.186^{* * *}$ \\
\hline $\mathrm{H} 8$ & $\mathrm{~TB} \rightarrow \mathrm{SA}$ & $0.227 * * *$ & $\mathrm{Y}$ & $0.386 * * *$ \\
\hline H9 & $\mathrm{PE} \rightarrow \mathrm{SA}$ & $0.106^{* *}$ & $\mathrm{Y}$ & $0.389 * * *$ \\
\hline $\mathrm{H} 10$ & $\mathrm{PU} \rightarrow \mathrm{LO}$ & 0.019 & $\mathrm{~N}$ & $0.153^{* *}$ \\
\hline $\mathrm{H} 11$ & $\mathrm{~TB} \rightarrow \mathrm{LO}$ & 0.096 & $\mathrm{~N}$ & 0.083 \\
\hline $\mathrm{H} 12$ & $\mathrm{PE} \rightarrow \mathrm{LO}$ & $0.067 * *$ & $\mathrm{Y}$ & $0.455^{* * *}$ \\
\hline H13 & $\mathrm{HA} \rightarrow \mathrm{CI}$ & $0.329 * * *$ & $\mathrm{Y}$ & $0.304 * * *$ \\
\hline \multirow{2}{*}{ H14 } & $\mathrm{PU} \rightarrow \mathrm{CI}$ & $0.094 *$ & \multirow{2}{*}{$\mathrm{Y}$} & \multirow{2}{*}{$-0.146^{*}$} \\
\hline & $\mathrm{HA} \rightarrow \mathrm{CI}$ & $0.329 * * *$ & & \\
\hline \multirow{2}{*}{ H15 } & $\mathrm{TB} \rightarrow \mathrm{CI}$ & 0.044 & \multirow{2}{*}{$\mathrm{N}$} & \multirow{2}{*}{-0.059} \\
\hline & $\mathrm{HA} \rightarrow \mathrm{CI}$ & $0.329 * * *$ & & \\
\hline \multirow{2}{*}{ H16 } & $\mathrm{PE} \rightarrow \mathrm{CI}$ & $0.081 * *$ & \multirow{2}{*}{ Y } & \multirow{2}{*}{-0.014} \\
\hline & $\mathrm{HA} \rightarrow \mathrm{CI}$ & $0.329 * * *$ & & \\
\hline $\mathrm{H} 17$ & $\mathrm{EE} \rightarrow \mathrm{CI}$ & $0.079 *$ & $\mathrm{Y}$ & \\
\hline H18 & $\mathrm{CL} \rightarrow \mathrm{CI}$ & $0.085 * *$ & $\mathrm{Y}$ & \\
\hline H19 & $\mathrm{CL} \rightarrow \mathrm{EE}$ & $0.319^{* * *}$ & $\mathrm{Y}$ & \\
\hline $\mathrm{H} 20$ & $\mathrm{EE} \rightarrow \mathrm{PR}$ & $0.269 * *$ & $\mathrm{Y}$ & \\
\hline $\mathrm{H} 21$ & $\mathrm{CL} \rightarrow \mathrm{PR}$ & $0.178^{* * *}$ & $\mathrm{Y}$ & \\
\hline $\mathrm{H} 22$ & $\mathrm{PR} \rightarrow \mathrm{CI}$ & $-0.062 * * *$ & $\mathrm{Y}$ & \\
\hline
\end{tabular}

Our research extends the integrated model of Gwebu et al. [2] to examine users' continuance intention toward Yu'e Bao. So, we compared our results with those of Gwebu et al. [2], as shown in Tab. 5. Overall, except H10 and H16, other results were similar to the study of Gwebu et al. [2]. Moreover, H17-H22 are supported.

\section{DISCUSSION AND CONCLUSION}

The purpose of this study is to put forward and validate an extended DPM within the context of Internet investment products. We explore the antecedents of continuance intention to use Yu'e Bao, as an example of Internet investment products by analysing the role of perceived usefulness, trusting beliefs, perceived enjoyment, satisfaction, loyalty, habit, expected earnings, capital liquidity and perceived risk. The first evaluates the results related to the relationships between the different DPM variables that eventually motivate continuance usage intention of Yu'e Bao. The second examines the influence of external variables, namely, expected earnings, capital liquidity and perceived risk on continuance intention of using Yu'e Bao.

The results show that perceived usefulness, perceived enjoyment, satisfaction, loyalty and habit have positive impacts on users' continuance intentions toward Yu'e Bao, which are consistent with the research of Gwebu et al.
(2014) [2]. Moreover, our results also show that habit mediates the relationship between perceived usefulness and continuance intention, and also mediates the relationship between perceived enjoyment and continuance intention.

Our findings point out that perceived usefulness and trusting beliefs have no important impacts on users' loyalty toward Yu'e Bao. This means the utilitarian values of Yu'e Bao may not necessarily improve user loyalty. In fact, IT innovations had proliferated and so had the amount of incidences of users that transfer from one IT to another [4547]. Users could freely switch between different IT products such as operating systems (e.g., Windows, Linux), office productivity software (e.g., Microsoft Office, WPS), web browsers (e.g., Internet Explorer, Sogou browser), and social networking services software (e.g. Facebook, Myspace, WeChat, Microblog).

Our findings also point out that an individual's intention to continue to use Yu'e Bao is effected by the additional variables proposed in this study, namely expected earnings, capital liquidity and perceived risk. Although expected earnings, capital liquidity and perceived risk have been examined in the financial sector, IS literature did not pay enough attention to these concepts and their effects on post-adoption intentions and actions. Our findings suggest that expected earnings and capital liquidity have positive impacts on users' continuance intention toward Yu'e Bao. Perceived risk has negative influence on continuance intention toward Yu'e Bao. Moreover, the results also demonstrate that expected earnings and capital liquidity have positive impacts on users' perceived risk toward Yu'e Bao. The capital liquidity has negative influence on expected earnings. Therefore, there are very complex relationships between the four variables (expected earnings, capital liquidity, perceived risk and continuance intention).

The results also provide important implications for practice. Firstly, usefulness and enjoyment positively impact satisfaction and continuance usage intention, which highlight the role of the critical driver, namely service utility and entertainment experience, in continuance decisions of Yu'e Bao. Although Yu'e Bao is primarily an investment product, it also should provide user with selffulfilling value and pleasure. Secondly, the results show that the continuous intention of Yu'e Bao users can be enhanced in a variety of ways, such as improving user affections and emotions, enhancing positive user perception, and promoting the habitual use of Yu'e Bao. In addition, a comprehensive strategy for beliefs, affections, and habit will be more effective than a strategy for each component alone. Lastly, expected earnings and capital liquidity are two very important factors in attracting users to adopt and continue to use Internet investment products, but they also positively and significantly impact user perceived risk. Therefore, the Internet financial platform needs to achieve a balance between the expected earnings, capital liquidity and perceived risk.

Our study also has some limitations. Firstly, we only use an internet investment product to validate research models and hypotheses. Although Yu'e Bao is one of the most widely used Internet investment products in China, so the results of this research may not directly extend to other Internet investment products. Secondly, we use the 
respondent-driven sampling method to collect data. Because of the management of the data collection process, this approach may reduce the randomness of the sample and limit the external validity of the research model. In addition, because college students cannot represent all Yu'e Bao users, our samples also have certain biases.

\section{Acknowledgements}

This paper is supported by the National Natural Science Foundation of China (No: 71764006, No: 71363022, No: 71361012), Natural Science Foundation of Jiangxi, China (No: 20161BAB201029) and Foundation of Jiangxi Educational Committee (No: GJJ170335).

\section{REFERENCES}

[1] CNNIC. (2017). Statistical Report on Internet Development in China. Retrieved from http://www.cnnic.net.cn/hlwfzyj/ hlwxzbg/hlwtjbg/201701/P020170123364672657408.pdf

[2] Gwebu, K., Wang, J., \& Guo, L. (2014). Continued usage intention of multifunctional friend networking services: A test of a dual-process model using Facebook. Decision Support Systems, 67(12), 66-77. https://doi.org/10.1016/j.dss.2014.08.004

[3] Lin, S. (2017). Identify predictors of university students' continuance intention to use online carbon footprint calculator. Behaviour \& Information Technology, 36(3), 294-311. https://doi.org/10.1080/0144929X.2016.1232751

[4] Park, S.O., Na, H. J., \&Kwon, O. (2016). Comparative effect of company-driven SNS activity vs. consumer-driven SNS activity on firm value: Evidence from Facebook. Computers in Industry, 82, 186-195. https://doi.org/10.1016/j.compind.2016.07.008

[5] Albashrawi, M. \& Motiwalla, L. (2015). The Moderating Effect of Privacy and Personalization in Mobile Banking: A Structural Equation Modeling Analysis. AMCIS 2015, Twenty-first Americas Conference on Information Systems, Puerto Rico.

[6] Eljelly, A. M. A. (2014). Liquidity-profitability trade off: An empirical investigation in an emerging market. International Journal of Commerce \& Management, 14(2), 48-61. https://doi.org/10.1108/10569210480000179

[7] Aldas-Manzano, J., Lassala-Navarre, C., Ruiz-Mafe, C., \& Sanz-Blas, S. (2009). Key drivers of Internet banking services use. Online Information Review, 33(4), 672-695. https://doi.org/10.1108/14684520910985675

[8] Deutsch, R. \& Strack, F. (2006). TARGET ARTICLE: duality models in social psychology: from dual processes to interacting systems. Psychological Inquiry, 17(3), 166-172. https://doi.org/10.1207/s15327965pli1703_2

[9] Evans, J. S. B. T. (2008). Dual-processing accounts of reasoning, judgment, and social cognition. Annual Review of Psychology, 59(1), 255-278. https://doi.org/10.1146/annurev.psych.59.103006.093629

[10] Zhao, K., Stylianou, A.C., \& Zheng. Y. (2013). Predicting users' continuance intention in virtual communities: the dual intention-formation processes. Decision Support Systems, 55(4), 903-910. https://doi.org/10.1016/j.dss.2012.12.026

[11] Zhang, L., Zhu, J., \& Liu, Q. (2012). A meta-analysis of mobile commerce adoption and the moderating effect of culture. Computers in Human Behavior, 28(5), 1902-1911. https://doi.org/10.1016/j.chb.2012.05.008

[12] Oliver, R. L. (1993). Cognitive, affective, and attribute bases of the satisfaction response. Journal of Consumer Research, 20(3), 418-430. https://doi.org/10.1086/209358
[13] Oliver, R. L. (1980). A cognitive model of the antecedents and consequences of satisfaction decisions. Journal of Marketing Research, 17(4), 460-469. https://doi.org/10.2307/3150499

[14] Bhattacherjee, A. (2001). Understanding information systems continuance: An expectation-confirmation model. MIS Quarterly, 25(3), 351-370. https://doi.org/10.2307/3250921

[15] Oliver, R. L. (1999). Whence consumer loyalty? Journal of Marketing, 63(4), 33-44. https://doi.org/10.2307/1252099

[16] Liu, Q. (2013). U-commerce research: A literature review and classification. International Journal of Ad Hoc and Ubiquitous Computing, 12(3), 177-187. https://doi.org/10.1504/IJAHUC.2013.052414

[17] Liu, Q. \& Zhang, L. (2014). Information cascades in online reading: An empirical investigation of panel data. Library $\mathrm{Hi}$ Tech, 32(4), 687-705. https://doi.org/10.1108/LHT-06-2014-0052

[18] Liu, Q., Huang, S., \& Zhang, L. (2016). The influence of information cascades on online purchase behaviors of search and experience products. Electronic Commerce Research, 16(4), 553-580. https://doi.org/10.1007/s10660-016-9220-0

[19] Liu, Q., Zhang, X., Zhang, L., \& Zhao, Y. (2018). The interaction effects of information cascades, word of mouth and recommendation systems on online reading behavior: An empirical investigation. Electronic Commerce Research. https://doi.org/10.1007/s10660-018-9312-0

[20] Chaudhuri, A. \& Holbrook, M.B. (2011). The chain of effects from brand trust and brand affect to brand performance: the role of brand loyalty. Journal of Marketing, 65(2), 81-93. https://doi.org/10.1509/jmkg.65.2.81.18255

[21] Lu, H. P. \& Wang, S. (2008). The role of Internet addiction in online game loyalty: an exploratory study. Internet Research, 18(5), 499-519. https://doi.org/10.1108/10662240810912756

[22] Verplanken, B. \& Orbell, S. (2003). Reflections on past behavior: A self-report index of habit strength. Journal of Applied Social Psychology, 33(6), 1313-1330. https://doi.org/10.1111/j.1559-1816.2003.tb01951.x

[23] Limayem, M., Hirt, S. G., \& Cheung, C. M. K. (2007). How Habit Limits the Predictive Power of Intention: The Case of Information Systems Continuance. MIS Quarterly, 31(4), 705-737. https://doi.org/10.2307/25148817

[24] Chiu, C., Hsu, M., Lai, H., \& Chang, C. (2012). Reexamining the influence of trust on online repeat purchase intention: the moderating role of habit and its antecedents. Decision Support Systems, 53(4), 835-845. https://doi.org/10.1016/j.dss.2012.05.021

[25] Zhao, K., Stylianou, A. C., \& Zheng. Y. (2013). Predicting users' continuance intention in virtual communities: the dual intention-formation processes. Decision Support Systems, 55(4), 903-910. https://doi.org/10.1016/j.dss.2012.12.026

[26] Chen, C. P., Lai, H. M., \& Ho, C. Y. (2015). Why do teachers continue to use teaching blogs? The roles of perceived voluntariness and habit. Computers \& Education, 82(3), 236-249. https://doi.org/10.1016/j.compedu.2014.11.017

[27] Kim, S. S. \& Malhotra, N. K. (2005). A longitudinal model of continued IS use: an integrative view of four mechanisms underlying post-adoption phenomena. Management Science, 51(5), 741-755. https://doi.org/10.1287/mnsc. 1040.0326

[28] Chen, S. C. (2012). To use or not to use: understanding the factors affecting continuance intention of mobile banking. International Journal of Mobile Communications, 10(5), 490-507. https://doi.org/10.1504/IJMC.2012.048883

[29] Chen, D., Lou, H., \& Slyke, C. V. (2015). A Study on Factors Influencing the Adoption Willingness of Internet Finance Customers in China. Communications of the Association for Information System, 36(17), 317-336.

[30] Laukkanen, T. (2016). Consumer adoption versus rejection decisions in seemingly similar service innovations: The case 
of the Internet and mobile banking. Journal of Business Research, 69(7), 2432-2439. https://doi.org/10.1016/j.jbusres.2016.01.013

[31] Lee, S. (2017). Evaluation of Mobile Application in User's Perspective: Case of P2P Lending Apps in FinTech Industry. KSII Transactions on Internet \& Information Systems, 11(2), 1105-1117.

[32] Featherman, M. S. \& Pavlou, P. A. (2003). Predicting eservices adoption: a perceived risk facets perspective. International Journal of Human-Computer Studies, 59(4), 451-474. https://doi.org/10.1016/S1071-5819(03)00111-3

[33] Ostlund, L. E. (1974). Perceived Innovation Attributes as Predictors of Innovativeness. Journal of Consumer Research, 1, 23-29. https://doi.org/10.1086/208587

[34] Zhang, Z. Y., \&Xiang, M. Y. (2017). Risk Measuring of Internet Financial Structural Products Based on Garch-EVTCopula. Management Science and Engineering, 11 (1), 5466.

[35] Balladares, G., Miralles, F., \& Kennett, C. (2017). The Role of Perceived Risk in Online Information Search and Prepurchase Alternative Evaluation of Products with Significant Experiential Attributes. In: Kavoura A., Sakas D., Tomaras P. (eds) Strategic Innovative Marketing. Springer Proceedings in Business and Economics. Springer, Cham, 283-289. https://doi.org/10.1007/978-3-319-33865-1_36

[36] Xinhua. (2017). Alibaba's Yu'e Bao becomes largest money market fund globally. Retrieved from http://news.xinhuanet.com/english/2017-04/28/c 136243985.htm

[37] Lin, K.-Y. \& Lu, H.-P. (2011). Why people use social networking sites: An empirical study integrating network externalities and motivation theory. Computers in Human Behavior, 27(3), 1152-1161. https://doi.org/10.1016/j.chb.2010.12.009

[38] Lin, C. P. \& Bhattacherjee, A. (2008). Elucidating individual intention to use interactive information technologies: the role of network externalities. International Journal of Electronic Commerce, 13(1), 85-108. https://doi.org/10.2753/JEC1086-4415130103

[39] Kim, S. S. \& Son, J. (2009). Out of dedication or constraint? A dual model of post-adoption phenomena and its empirical test in the context of online services. MIS Quarterly, 33(1), 49-70. https://doi.org/10.2307/20650278

[40] Kang, Y. S., Hong, S., \& Lee, H. (2009). Exploring continued online service usage behavior: The roles of selfimage congruity and regret. Computers in Human Behavior, 25(1), 111-122. https://doi.org/10.1016/j.chb.2008.07.009

[41] Lee, M. C. (2009). Predicting and explaining the adoption of online trading: An empirical study in Taiwan. Decision Support Systems, 47(2), 133-142. https://doi.org/10.1016/j.dss.2009.02.003

[42] Mouakket, S. (2015). Factors influencing continuance intention to use social network sites: The Facebook case. Computers in Human Behavior, 53, 102-110. https://doi.org/10.1016/j.chb.2015.06.045

[43] Hair, J. F., Anderson, R. E., Tatham, R. L., \& Black, W. C. (1998). Multivariate data analysis $\left(5^{\text {th }}\right.$ ed.). Englewood Cliffs, NJ: Prentice Hall.

[44] Fornell, C. \& Larcker, D. (1981). Evaluating structural equation models with unobservable variables and measurement error. Journal of Marketing Research, 18(1), 39-50. https://doi.org/10.2307/3151312

[45] Bhattacherjee, A. \& Park, S. C. (2004). Why end-users move to the cloud: a migration-theoretic analysis. European Journal of Information Systems, 23, 357-372. https://doi.org/10.1057/ejis.2013.1

[46] Peng, X., Zhao, Y., \& Zhu, Q. (2016). Investigating user switching intention for mobile instant messaging application: Taking WeChat as an example. Computers in Human Behavior, 64, 206-216. https://doi.org/10.1016/j.chb.2016.06.054

[47] Jung, J., Han, H., \& Oh, M. (2017). Travellers' switching behavior in the airline industry from the perspective of the push-pull-mooring framework. Tourism Management, 59, 139-153. https://doi.org/10.1016/j.tourman.2016.07.018

\section{Contact information:}

Qihua LIU, PhD

School of Information Technology,

Jiangxi University of Finance and Economics,

Nanchang 330013, PR China

qh_liu@163.com

Fuguo ZHANG, PhD

School of Information Technology,

Jiangxi University of Finance and Economics,

Nanchang 330013, PR China

redbird_mail@163.com

Mingsong MAO, PhD

School of Information Technology,

Jiangxi University of Finance and Economics,

Nanchang 330013, PR China

Mingsongmao@jxufe.edu.cn

Bingyu XUE, BSC

School of Information Technology,

Jiangxi University of Finance and Economics,

Nanchang 330013, PR China

xby1790@163.com

\section{Zhifang LIN, MSc}

(Corresponding author)

Modern Economics and Management College, Jiangxi University of Finance and Economics, Nanchang 330013, PR China

yidaiwo@163.com 